\title{
Kinetics of blood free and milk casein-amino acid labelling in the dairy goat at two stages of lactation
}

\author{
BY B. J. BEQUETTE ${ }^{1 *}$, F. R. C. BACKWELL ${ }^{1}$, M. S. DHANOA ${ }^{3}$, A. WALKER ${ }^{1}$, \\ A. G. CALDER ${ }^{1}$, D. WRAY-CAHEN ${ }^{2}$, J. A. METCALF ${ }^{2}$, J. D. SUTTON ${ }^{2,3}$, \\ D. E. BEEVER ${ }^{2}$, G. E. LOBLEY ${ }^{1}$ AND J. C. MACRAE ${ }^{1}$ \\ ${ }^{1}$ Rowett Research Institute, Bucksburn, Aberdeen AB2 9SB \\ ${ }^{2}$ Centre for Dairy Research, University of Reading, Reading RG6 $2 A T$ \\ ${ }^{3}$ AFRC Institute for Grassland and Environmental Research Plas Gogerddan, \\ Aberystwyth SY23 3EB
}

(Received 6 September 1993 - Revised 29 November 1993-Accepted 14 December 1993)

\begin{abstract}
The kinetics of blood free amino acids (AA) transfer into milk casein were compared in goats $(n$ 4) at 61 (SE 5) d (Expt 1; post-peak, 4.51 (SE 0.26) kg milk/d) and at 180 (SE 6) d (Expt 2; late, 2.36 (SE 0.16) kg milk/d) of lactation during non-primed, continuous (Expt 1, 12 h; Expt 2, 16 h) intravenous infusions of mixtures of $L-\left[1-{ }^{13} \mathrm{C}\right]$ leucine and $L-\left[1-{ }^{13} \mathrm{C}\right]$ phenylalanine with either $\mathrm{L}-\left[1-{ }^{13} \mathrm{C}\right]$ valine (Expt 1 ) or L-[5- $\left.{ }^{13} \mathrm{C}\right]$ methionine (Expt 2). The ${ }^{13} \mathrm{C}$ enrichments of blood free and casein-bound AA were fitted to a single exponential model to estimate isotopic plateaux and the fractional rate constant for milk casein labelling. Milk protein output and its contribution to whole-body flux was higher in Expt 1 (post-peak) than in Expt 2 (late lactation), but the kinetics of ${ }^{13} \mathrm{C}$ labelling of the casein-bound AA were similar for all $A A$ tracers in both experiments. At both stages of lactation the delay $(6-8 \mathrm{~h})$ between the attainment of isotopic plateau for the blood free AA and the corresponding attainment of plateau for the caseinbound $\mathrm{AA}$ indicated that the blood free pool was not the immediate precursor pool for milk casein biosynthesis. Plateau enrichments of casein-bound AA were generally higher than those for the corresponding blood free $\mathrm{AA}$ in both experiments. These results indicate that the relative contributions of different AA sources to the immediate precursor pool for milk casein biosynthesis are similar at different stages of lactation despite major changes in the partitioning of whole-body flux towards milk protein output. Non-milk protein fluxes were also similar in post-peak and late lactation.
\end{abstract}

Milk protein: Amino acid kinetics: Casein: Lactating goats

Lactation requires a major increase in the partitioning of amino acids (AA) towards the mammary gland for milk protein synthesis $(31-46 \%$ of whole-body protein flux compared with 1-6\% in dry, non-pregnant animals; Champredon et al. 1990; Baracos et al. 1991). However, milk protein output represents only a proportion (40-60\%) of total protein synthesis in the lactating mammary gland (Oddy et al. 1988; Champredon et al. 1990; Baracos et al. 1991) and therefore approximately half of the synthesized protein must be degraded, assuming that there is no appreciable net gain by the mammary tissue protein pool. This may represent either general turnover of both constitutive and milk proteins, or a specific channelling of milk protein precursor AA through protein(s) which constitutes an intermediate mixing pool(s).

The results of Oddy et al. (1988) would seem to indicate that the latter phenomenon exists, but their study involved only short-term infusions of a single AA tracer (leucine) which is known to be extensively metabolized by the gland. The present study involved the

\footnotetext{
* For reprints.
} 
examination of four separate AA tracers representative of those which are either extensively metabolized (leucine and valine) or not (phenylalanine and methionine) by the gland. Each tracer was infused intravenously for extended periods (12-16 h) during early (post-peak) and late lactation in order to compare the blood-to-casein transfer kinetics over a period when the mammary gland contribution to whole-body protein metabolism diminishes. Such information should help provide a better understanding of the dynamics of milk-protein synthesis for use in future mechanistic models of lactation aimed at predicting milk constituent outputs (MacRae et al. 1988), and the key points of regulation which could be manipulated to alter milk protein content and yield.

\section{MATERIALS AND METHODS}

Isotopes

Specific mixtures of $\mathrm{L}-\left[1-{ }^{13} \mathrm{C}\right]$ leucine, $\mathrm{L}-\left[1-{ }^{13} \mathrm{C}\right]$ valine, $\mathrm{L}-\left[1 \mathrm{1}^{13} \mathrm{C}\right]$ phenylalanine (Tracer Technologies Inc., Somerville, MA, USA) and L- $\left[5-{ }^{13} \mathrm{C}\right]$ methionine (all 99 atoms \%; Cambridge Isotope Laboratories, MA, USA) were dissolved in sterile saline $(9 \mathrm{~g} \mathrm{NaCl} / 1)$ and infused continuously into a jugular vein at rates approximating to $5 \%$ of whole-body AA flux.

\section{Animals and feeds}

Two experiments were conducted with six non-pregnant, lactating (primiparous) British Saanen goats (mean body weight 58.4 (SD 4.9) kg) between days 51-71 (Exp 1, $n$ 4) and 162-184 (Expt 2, n 4) of lactation. Animals used in Expt 2 had been surgically prepared with carotid artery and mammary vein (superficial epigastric vein) skin-covered loops not less than 1 month before the experiment, and two of these animals (nos. 19 and 20) had been used in Expt 1. For both experiments animals were placed in metabolism cages $10 \mathrm{~d}$ before isotope infusion to allow acclimatization to the daily routine of machine and hand milking (08.30 and 16.30 hours) and frequent feeding via automatic feeders $(12 \times 2 \mathrm{~h})$. The diets for the two experiments consisted of fixed dry matter (DM) proportions (Expt 1, 40:60, Expt 2, 60:40) of chopped grass-hay (molassed) and pelleted concentrate providing 124 and $95 \mathrm{~g}$ digestible crude protein and 12.9 and $11.8 \mathrm{MJ}$ metabolizable energy $(\mathrm{ME}) / \mathrm{kg} \mathrm{DM}$ respectively. According to the amounts consumed in $\operatorname{Expt} 1(2.6 \mathrm{~kg} \mathrm{DM} / \mathrm{d})$, goats received approximately $230 \mathrm{~g}$ metabolizable protein (MP) and $33 \mathrm{MJ} \mathrm{ME} / \mathrm{d}$ (as calculated from relationships described by the Agricultural and Food Research Council (1984, 1992)). These intakes matched their daily estimated requirements for maintenance plus $4.5 \mathrm{~kg}$ milk of $240 \mathrm{~g} \mathrm{MP}$ and $31 \mathrm{MJ} \mathrm{ME} \mathrm{(Agricultural} \mathrm{and} \mathrm{Food} \mathrm{Research} \mathrm{Council,}$ 1984, 1992). In Expt 2, intakes (2.5 kg DM/d) provided $208 \mathrm{~g} \mathrm{MP}$ and $30 \mathrm{MJ} \mathrm{ME}$ which was in excess of their calculated requirements $(150 \mathrm{~g} \mathrm{MP}$ and $21 \mathrm{MJ} \mathrm{ME} / \mathrm{d})$ for maintenance plus $2.4 \mathrm{~kg}$ milk/d. Milk weights were recorded at each milking and subsamples were stored for subsequent analyses.

At least $1 \mathrm{~d}$ before an isotope infusion, temporary catheters (polyvinyl chloride; Critchley Electrical Products, NSW, Australia) were placed in appropriate vessels (external jugular vein, Expt 1 and 2; carotid artery, Expt 2) following an intradermal injection of an analgesic ( $2 \%$ lignocaine hydrochloride). Catheters were filled and kept patent by flushing daily with heparinized saline (50 IU heparin/ml).

\section{Isotope infusion protocols}

In Expt 1 each animal received a non-primed, continuous infusion via the jugular vein of a mixture of $\left[1{ }^{13} \mathrm{C}\right]$ leucine $(71 \mathrm{mg} / \mathrm{h}),\left[1-{ }^{13} \mathrm{C}\right]$ valine $(37 \mathrm{mg} / \mathrm{h})$ and $\left[1-{ }^{13} \mathrm{C}\right]$ phenylalanine $(36 \mathrm{mg} / \mathrm{h}$ ) for $12 \mathrm{~h}$. The infusion commenced after the morning milking, when total milk 
letdown and removal was accomplished by a single intravenous injection of 1 IU oxytocin and machine and hand milking. Thereafter during the infusion the glands were milked-out completely by hand at hourly intervals, and the samples processed, as described later, to provide a temporal picture of labelling of milk protein. Contra-lateral jugular vein blood samples $(5 \mathrm{ml})$ were collected hourly throughout the infusion.

In Expt 2 each animal received a non-primed, continuous infusion via the jugular vein of a mixture of $\left[1-{ }^{13} \mathrm{C}\right]$ leucine $(67 \mathrm{mg} / \mathrm{h}),\left[1-{ }^{13} \mathrm{C}\right]$ phenylalanine $(38 \mathrm{mg} / \mathrm{h})$ and $\left[5-{ }^{13} \mathrm{C}\right]-$ methionine $(12 \mathrm{mg} / \mathrm{h})$ for $16 \mathrm{~h}$, the length of the infusion being extended beyond the $12 \mathrm{~h}$ period employed in Expt 1 in an attempt to ensure that casein enrichment had reached 'plateau'. As in Expt 1 the goats were milked-out before the infusion, but without the use of oxytocin, and frequently thereafter. Carotid artery blood samples $(5 \mathrm{ml})$ were collected hourly for the first $8 \mathrm{~h}$ and two-hourly thereafter. Jugular vein blood samples $(5 \mathrm{ml})$ were also taken at $2 \mathrm{~h}$ intervals during the last $6 \mathrm{~h}$ of the infusion to assess, by comparison of AA enrichments in jugular and arterial samples, the extent of isotope dilution across the head. In both experiments, blood and milk samples were taken at least $24 \mathrm{~h}$ before isotope infusion for assessment of $\left[{ }^{13} \mathrm{C}\right]$ natural abundance.

\section{Analytical methods}

Blood analyses. Blood was collected into ice-cold tubes containing heparin (4 IU $/ \mathrm{ml} \mathrm{blood)}$ and placed on ice until processed (within approximately $30 \mathrm{~min}$ ). For storage, whole blood $(1 \mathrm{ml})$ was haemolysed by the addition of an equal volume of ice-cold water, mixed and either stored at $-20^{\circ}$ (Expt 1 ) or freeze-dried to dryness and stored at $-80^{\circ}$ to minimize oxidative losses of methionine (Expt 2).

Stored blood samples were deproteinized by the addition of $0.5 \mathrm{ml}$ ice-cold sulphosalicylic acid $(380 \mathrm{~g} / 1)$ and centrifugation at $800 \mathrm{~g}\left(20 \mathrm{~min}, 4^{\circ}\right)$. Lyophilized blood was first reconstituted in ice-cold distilled water $(2 \mathrm{ml})$ before deproteinization. Amino acids were isolated and converted to the tertiary-butyldimethylsilyl derivative for electron-impact gas chromatography-mass spectrometry (GC-MS ; Trio-1; VG Masslab., Manchester) determination of $\left[{ }^{13} \mathrm{C}\right]$ AA atom percent excess (APE) as described by Calder \& Smith (1988). Data are presented as APE with respect to the pre-infusion natural abundance of the free AA.

Milk analyses. Milk-N assays were determined on sub-samples (about $35 \mathrm{~g}$ ) taken during the $2-4 \mathrm{~d}$ before isotope infusion. The samples were preserved with $0.1 \mathrm{ml}$ formaldehyde and stored frozen $\left(-20^{\circ}\right)$ before analysis by the Kjeldahl method. Milk protein output was calculated as (milk $\mathrm{N} \times 6.38$ ).

Milk samples taken during isotope infusion were immediately placed on ice and within $4 \mathrm{~h}$ were processed to separate the total casein and whey proteins from other milk constituents by a modification of the method of McKenzie (1971). The casein pellet was twice precipitated ( $\mathrm{pH} \mathrm{4.5-4.6)}$ and solubilized $(\mathrm{pH} \mathrm{7 \cdot 0-7 \cdot 2)}$ before freeze-drying and storage at $-20^{\circ}$. The purified casein $(30 \mathrm{mg})$ was dialysed against water and hydrolysed in $6 \mathrm{M}-\mathrm{HCl}$ (containing $0.5 \mathrm{~g}$ dithiothreitol/1 to protect methionine residues) at $110^{\circ}$ for $18 \mathrm{~h}$. The liberated AA were purified and derivatized for GC-MS as described above. The data are presented as APE with respect to the pre-infusion natural abundance of the caseinbound AA.

\section{Calculations}

The individual AA flux rates (rate of irreversible loss of AA from blood) were calculated according to the following equation: flux $(\mathrm{mmol} / \mathrm{d})=\left(\left(\mathrm{E}_{\mathrm{i}} / \mathrm{E}_{\mathrm{b}}\right)-1\right) \times \mathrm{IR} \times 24$, where $\mathrm{E}_{\mathrm{i}}$ and $E_{b}$ are the enrichments of the free $A A$ in the infusate and at predicted plateau in the blood respectively, and IR is the isotope infusion rate $(\mathrm{mmol} / \mathrm{h})$. The proportional contribution 
of AA output in milk protein to whole-body flux (proportional flux $x_{m}$ ) was calculated as follows: $((\mathrm{g}$ milk $\mathrm{N} / \mathrm{d} \times 6.38) \times \mathrm{C}) /$ flux, where $\mathrm{C}$ is the individual AA content of casein (leucine 0.74, phenylalanine 0.32, valine 0.59 and methionine $0.21 \mathrm{mmol} / \mathrm{g}$; Eggum, 1968). Calculations were simplified by assuming the AA composition of casein since it dominates $(78 \%)$ the milk protein $\mathrm{N}$ fraction and negligible differences in the composition of the various milk proteins exist.

\section{Statistics}

The ${ }^{13} \mathrm{C}$ enrichments of the individual $\mathrm{AA}$ in blood and casein were best described by a single exponential model: $\mathrm{y}=\mathrm{A}+\mathrm{B} \mathrm{e}^{-k t}$, where $\mathrm{y}$ is isotope concentration (APE) at time $t$ (h), A is the plateau APE (blood, $A_{b}$; casein, $A_{c}$ ), B is the increase from baseline value to plateau APE and $k$ is the fractional rate constant (per $\mathrm{h}$; determined for casein only and denoted as $k_{c}$ ). However, since the rise to plateau in blood was fairly rapid, only a limited number of sampling points described this phase and these data were therefore subjected to linear spline analysis (with second-phase horizontal), by transforming the data to a logarithmic scale. With the casein data, in an attempt to avoid any effect of the initial lag on the fitted parameters, the data in the early phase were omitted initially and the iterative processing was continued, and as a result it was only necessary to exclude the first time point. Linear spline analysis was considered inappropriate for the casein APE data since in some cases the plateau was reached only near or beyond the end of the data set.

Comparisons of whole-body AA flux, proportional flux $\mathrm{m}_{\mathrm{m}}$ and $k_{c}$ were performed by oneway ANOVA, with differences between group means evaluated by use of the $t$ statistic. Differences between the estimates of isotopic plateaux in milk casein $\left(A_{c}\right)$ and in jugular or arterial blood $\left(\mathrm{A}_{\mathrm{b}}\right)$ from individual animals and amino acid tracers were determined by Student's $t$ test. Since animals nos. 19 and 20 were common to both experiments, the casein APE data from these were subjected to parallel curve analysis (Ross, 1987) for comparison of between-experiment values of $k_{c}$ from leucine and phenylalanine.

\section{RESULTS}

Milk production

Animals in Expt 1 were at day 61 (SE 5) of lactation (post-peak), and were producing 4.51 (SE 0.26) $\mathrm{kg}$ milk and 130 (SE 10) g milk protein/d. Animals in Expt 2 were at day 180 (SE 6) of lactation (late), and were producing $2 \cdot 36$ (SE 0.16) $\mathrm{kg}$ milk and 66 (SE 4) $\mathrm{g}$ milk protein/d.

\section{Whole-body amino acid and blood and milk casein labelling kinetics}

Expt 1. The kinetic variables from blood free and casein-bound AA in early (post-peak) lactating goats are shown in Table 1. For leucine, phenylalanine and valine, the predicted isotope enrichment plateaux in jugular blood $\left(A_{b}\right)$ were attained at 5.6 (SE 1.5), 5.8 (SE 2.4) and 6.3 (SE 1.8) h respectively. Whole-body AA flux rates were calculated from values of $A_{b}$ and, since body weights were variable, values are expressed $/ \mathrm{kg}$ body weight. There were significant differences $(P<0.001)$ between calculated AA flux rates, with leucine $>$ valine $>$ phenylalanine. However, the calculations of AA output in milk protein as a proportion of total body flux were similar for all three tracers (proportional flux $\mathrm{m}_{\mathrm{m}}$; overall mean 0.30 (SE 0.01); Table 1).

Fig. 1 illustrates the temporal changes in the mean ( $n 4$ for each time point) isotopic enrichment of leucine in jugular blood and in milk casein. Similar casein labelling patterns were observed for phenylalanine and valine. The rates of labelling of the casein-bound AA were much slower than those of jugular blood free AA. The predicted plateaux for enrichment of leucine, valine and phenylalanine in casein $\left(A_{c}\right)$ were attained only after $12 \cdot 2$ 
Table 1. Expt 1. Whole-body amino acid fluxes (estimated from predicted jugular venous blood plateau enrichment), proportional contribution of milk protein amino acid output to flux (proportional flux $x_{m}$ ), fractional rate constant for milk casein labelling $\left(\mathrm{k}_{\mathrm{c}}\right)$ and predicted isotopic plateaux of milk casein $\left(A_{c}\right)$ and jugular vein blood $\left(A_{b}\right)$ in post-peak (day 61 SE 5 ) lactation goats $\dagger$

\begin{tabular}{|c|c|c|c|c|c|c|c|c|}
\hline \multirow[b]{3}{*}{ Amino acid tracer } & \multirow{3}{*}{$\begin{array}{c}\text { Whole-body } \\
\text { amino acid flux } \\
(\mathrm{mmol} / \mathrm{d} \text { per } \mathrm{kg})_{\ddagger}^{+}\end{array}$} & \multirow{3}{*}{$\begin{array}{l}\text { Proportional } \\
\text { flux }_{m} \ddagger\end{array}$} & & & \multicolumn{4}{|c|}{ Predicted plateau (APE) } \\
\hline & & & \multicolumn{2}{|c|}{$k_{c}(/ \mathrm{h}) \ddagger$} & \multicolumn{2}{|c|}{$\mathbf{A}_{\mathrm{c}}$} & \multicolumn{2}{|c|}{$A_{b}$} \\
\hline & & & Mean & SE & Mean & $\mathrm{SE}$ & Mean & SE \\
\hline \multicolumn{9}{|l|}{$\left[1{ }^{13} \mathrm{C}\right]$ Leucine } \\
\hline Animal no. $19 \S$ & $5 \cdot 551$ & 0.29 & $0 \cdot 252$ & 0.015 & 4.50 & 0.08 & $4 \cdot 35$ & 0.65 \\
\hline $20 \S$ & 5.946 & 0.29 & 0.182 & $0 \cdot 019$ & $3 \cdot 33$ & $0 \cdot 15$ & $3 \cdot 00^{*}$ & 0.08 \\
\hline 9 & $5 \cdot 125$ & 0.28 & $0 \cdot 229$ & 0.014 & $4 \cdot 64$ & $0 \cdot 10$ & $4 \cdot 44$ & 0.13 \\
\hline 22 & 6.867 & 0.27 & 0.258 & 0.007 & $3 \cdot 40$ & 0.03 & $3 \cdot 16^{*}$ & 0.08 \\
\hline Group mean & $5 \cdot 872$ & $0 \cdot 28$ & 0.230 & & & & & \\
\hline \multicolumn{9}{|l|}{$\left[1-{ }^{13} \mathrm{C}\right]$ Phenylalanine } \\
\hline Animal no. $19 \S$ & $2 \cdot 222$ & $0 \cdot 31$ & 0.274 & $0 \cdot 018$ & $4 \cdot 31$ & $0-08$ & $4 \cdot 34$ & 0.65 \\
\hline $20 \S$ & $2 \cdot 282$ & $0 \cdot 32$ & 0.200 & 0.028 & 3.44 & $0 \cdot 19$ & $3 \cdot 36$ & 0.06 \\
\hline 9 & $2 \cdot 103$ & $0 \cdot 29$ & $0 \cdot 235$ & 0.015 & 4.53 & $0 \cdot 10$ & $4 \cdot 35$ & 0.33 \\
\hline 22 & $2 \cdot 547$ & $0 \cdot 31$ & 0.250 & 0.012 & 3.68 & 0.06 & $3 \cdot 60$ & $0 \cdot 10$ \\
\hline Group mean & $2 \cdot 289$ & $0 \cdot 31$ & $0 \cdot 240$ & & & & & \\
\hline \multicolumn{9}{|l|}{$\left[1{ }^{13} \mathrm{C}\right]$ Valine } \\
\hline Animal no. 19 & $4 \cdot 395$ & $0 \cdot 29$ & 0.171 & 0.017 & $3 \cdot 57$ & $0 \cdot 14$ & $3 \cdot 09^{*}$ & 0.05 \\
\hline 20 & $4 \cdot 435$ & $0 \cdot 31$ & 0.180 & 0.025 & 2.85 & $0-18$ & $2 \cdot 44^{*}$ & 0.07 \\
\hline 9 & 3.892 & $0 \cdot 30$ & 0.217 & 0.015 & 3.41 & 0.09 & $3 \cdot 36$ & $0 \cdot 19$ \\
\hline 22 & $5 \cdot 071$ & $0 \cdot 30$ & 0.251 & 0.015 & $2 \cdot 75$ & $0 \cdot 06$ & $2 \cdot 55^{*}$ & 0.07 \\
\hline Group mean & $4 \cdot 448$ & $0 \cdot 30$ & $0 \cdot 205$ & & & & - & \\
\hline
\end{tabular}

APE, atom percent excess.

Differences between predicted plateaux from individual animals and amino acid tracers were determined by use of Student's $t$ test: $* P<0.05$.

$\dagger$ For details of procedures and calculations, see pp. 212-214.

\$ Comparisons were performed using one-way ANOVA with differences between group means evaluated using the $t$ statistic. The appropriate standard error of difference values were, for 6 residual df, between amino acid tracer for calculations of whole-body amino acid flux 0.201 , proportional flux 0.01 and $k_{c} 0.018$. Differences between amino acid fluxes were significantly different $(P<0.001)$.

$\S$ Comparisons of leucine and phenylalanine kinetics for animals nos. 19 and 20 in Expts 1 and 2 were made using parallel curve analysis procedures (Ross, 1987). Values of $k_{c}$ were not different between experiments.

(SE 2.1), 11.7 (SE 1.6), and 13.8 (SE 2.4) h respectively. Most values of $\mathrm{A}_{\mathrm{c}}$ (casein) were higher than $A_{b}$ (jugular blood) and while these differences were not significant for phenylalanine they were significant $(P<0.05)$ for several animals for leucine and valine (see Table 1$)$. Although the values of $k_{c}$ for each of the individual tracer AA varied between animals, they were not statistically different in within-animal comparisons.

Expt 2. The kinetic variables for blood free and milk casein-bound AA in late lactation goats are given in Table 2. For leucine, phenylalanine and methionine, predicted plateaux in arterial blood $\left(A_{b}\right)$ were attained at $5 \cdot 7$ (SE 2.4), $2 \cdot 0$ (SE 0.3) and $4 \cdot 2$ (SE 3.4) h respectively. As in Expt 1, whole-body AA flux rates calculated from the individual tracer $A_{b}$ values were significantly different $(P<0.05)$ with leucine $>$ phenylalanine $>$ methionine but again the value of proportional flux $\mathrm{m}_{\mathrm{m}}$ was similar for each AA. The mean proportional flux $\mathrm{x}_{\mathrm{m}}$ value in Expt 2 (0.19, SE 0.03) was, however, considerably lower than the mean value in Expt 1 $(0 \cdot 30$, SE 0.01$)$ indicating that, in later lactation, milk-protein synthesis accounted for 


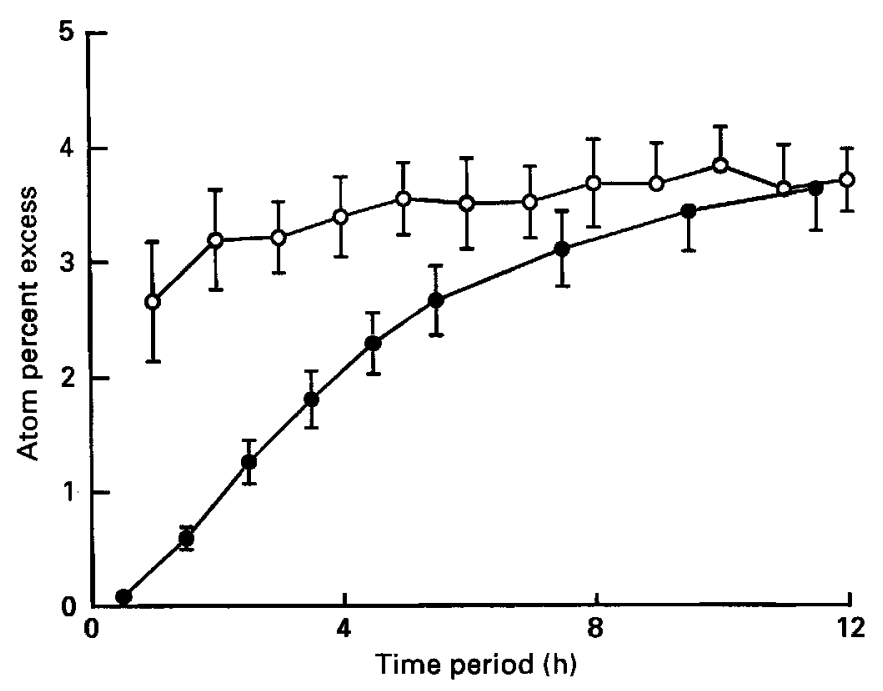

Fig, 1. Expt 1. Temporal changes in the isotopic enrichment of leucine in jugular vein blood $(O)$ and in secreted milk casein (O) during a $12 \mathrm{~h}$ non-primed, continuous infusion of $\mathrm{L}-\left[1-{ }^{13} \mathrm{C}\right]$ leucine. Values are means with their standard errors for four goats. Values for milk casein have been plotted at the mid-point between milking times and blood values at the time that the samples were withdrawn.

significantly less of whole-body flux. The non-milk protein synthesis component $(\mathrm{mmol} / \mathrm{d})$ of whole-body flux, i.e. (whole-body AA flux) $\times\left(1\right.$-proportional flux $\left.x_{m}\right)$, was similar between post-peak and late lactation when calculated for the two tracers used in both experiments (phenylalanine $1.58 v .1 .56, P>0.30$ and leucine $4.22 v .3 .72, P>0.10$ ).

Illustrated in Fig. 2 are the temporal changes in the mean ( $n 4$ for each time point) isotopic enrichment of leucine in arterial blood and in milk casein. As in Expt 1, the rate of rise in the labelling of casein-bound leucine was slower than that in blood free leucine. This was also the case with the phenylalanine and methionine data, the casein-bound leucine, phenylalanine and methionine predicted plateaux $\left(A_{c}\right)$ being achieved only after 13.2 (SE 5.8), 11.9 (SE 4.6) and 12.6 (SE 5.0) h respectively. With one exception (animal no. 20; methionine: $A_{b}>A_{c}, P<0.05$ ), the values of $A_{c}$ were, as in Expt 1, either equal to or higher than $\mathrm{A}_{\mathrm{b}}$. Also, as in Expt 1, for each of the AA, values of $k_{c}$ varied between animals but comparisons within animals showed no statistical differences. Because two of the animals (nos. 19 and 20) were used in both Expts 1 and 2, parallel curve analysis was used to compare values of $k_{c}$ for leucine and phenylalanine (used in both experiments) at the two stages of lactation; these were not significantly different.

Comparisons of the isotopic enrichment of free AA in arterial and jugular venous blood over the last $6 \mathrm{~h}$ of the infusion (i.e. during isotopic plateau) indicated that jugular blood enrichments were $7 \cdot 1$ (SE 2.5), $7 \cdot 5$ (SE 1.8) and 6.3 (SE 2.4) \% lower for leucine, phenylalanine and methionine respectively, than the corresponding values in arterial blood.

\section{DISCUSSION}

During early lactation the mammary gland is one of the most metabolically active tissues in the body. Previous reports indicate that in the dairy goat the lactating mammary gland accounts for as much as $46 \%$ of total-body protein synthesis, with $40-60 \%$ of this synthesized protein being secreted in milk (Oddy et al. 1988; Champredon et al. 1990; Baracos et al. 1991). The net AA demands of the lactating mammary gland must therefore 
Table 2. Expt 2. Whole-body amino acid fluxes (estimated from predicted arterial blood plateau enrichment), proportional contribution of milk protein amino acid output to flux (proportional flux $\left.x_{m}\right)$, fractional rate constant for milk casein labelling $\left(\mathrm{k}_{\mathrm{c}}\right)$ and predicted isotopic plateaux of milk casein $\left(A_{c}\right)$ and arterial blood $\left(A_{b}\right)$ in late (day 180 SE 6) lactation goats $\dagger$

\begin{tabular}{|c|c|c|c|c|c|c|c|c|}
\hline \multirow[b]{3}{*}{ Amino acid tracer } & \multirow{3}{*}{$\begin{array}{c}\text { Whole-body } \\
\text { amino acid flux } \\
\text { (mmol/d per } \mathbf{k g}) \ddagger\end{array}$} & \multirow{3}{*}{$\begin{array}{l}\text { Proportional } \\
\text { flux }_{\mathbf{m}} \downarrow\end{array}$} & & & \multicolumn{4}{|c|}{ Predicted plateau (APE) } \\
\hline & & & \multicolumn{2}{|c|}{$k_{c}(/ \mathrm{h})_{+}^{\dagger}$} & \multicolumn{2}{|c|}{$A_{c}$} & \multicolumn{2}{|c|}{$A_{b}$} \\
\hline & & & Mean & SE & Mean & SE & Mean & SE \\
\hline \multicolumn{9}{|l|}{$\left[1-{ }^{13} \mathrm{C}\right]$ Leucine } \\
\hline Animal no. $19 \S$ & $5 \cdot 257$ & $0 \cdot 18$ & 0.232 & 0.011 & $4 \cdot 31$ & 0.06 & $4 \cdot 08^{*}$ & $0 \cdot 10$ \\
\hline $20 \S$ & 3.944 & 0.15 & $0 \cdot 188$ & 0.013 & $4 \cdot 06$ & 0.09 & $4 \cdot 32$ & $0 \cdot 13$ \\
\hline 23 & 4.073 & $0 \cdot 23$ & 0.449 & 0.037 & 4.96 & 0.06 & 4.97 & 0.97 \\
\hline 24 & 4.965 & $0 \cdot 18$ & $0 \cdot 138$ & 0.019 & $4 \cdot 70$ & $0 \cdot 25$ & $4.09 *$ & 0.04 \\
\hline Group mean & $4 \cdot 560$ & $0 \cdot 19$ & $0 \cdot 252$ & & & & & \\
\hline \multicolumn{9}{|c|}{$\left[1{ }^{-13} \mathrm{C}\right]$ Phenylalanine } \\
\hline Animal no. $19 \S$ & $2 \cdot 098$ & $0 \cdot 19$ & $0 \cdot 245$ & 0.010 & $4 \cdot 69$ & 0.05 & $4 \cdot 63$ & $0 \cdot 10$ \\
\hline $20 \S$ & 1.653 & $0 \cdot 15$ & $0 \cdot 196$ & 0.014 & $4 \cdot 48$ & $0 \cdot 10$ & 4.67 & 0.09 \\
\hline 23 & 1.974 & $0 \cdot 20$ & 0.481 & $0 \cdot 043$ & $5 \cdot 58$ & 0.07 & $4 \cdot 73^{*}$ & 0.37 \\
\hline 24 & 1.942 & 0.20 & $0 \cdot 167$ & 0.021 & $4 \cdot 76$ & $0 \cdot 19$ & $4 \cdot 75$ & 0.06 \\
\hline Group mean & $1 \cdot 917$ & $0 \cdot 19$ & 0.272 & & & & - & \\
\hline \multicolumn{9}{|l|}{$\left[5-{ }^{13} \mathrm{C}\right]$ Methionine } \\
\hline Animal no. 19 & $1 \cdot 381$ & $0 \cdot 19$ & $0 \cdot 246$ & 0.027 & $2 \cdot 39$ & 0.07 & $2 \cdot 48$ & 0.08 \\
\hline 20 & $1 \cdot 117$ & 0.15 & 0.202 & 0.024 & $2 \cdot 14$ & 0.09 & $2 \cdot 36^{*}$ & 0.05 \\
\hline 23 & $1 \cdot 349$ & $0 \cdot 20$ & 0.409 & 0.029 & 2.92 & 0.04 & $2 \cdot 43^{*}$ & 0.06 \\
\hline 24 & $1 \cdot 292$ & $0 \cdot 20$ & $0 \cdot 147$ & $0 \cdot 024$ & $2 \cdot 54$ & $0 \cdot 16$ & $2 \cdot 49$ & $0 \cdot 04$ \\
\hline Group mean & $1 \cdot 285$ & 0.19 & $0 \cdot 251$ & & & & - & \\
\hline
\end{tabular}

APE, atom percent excess.

Differences between predicted plateaux from individual animals and amino acid tracers were determined by use of Student's $t$ test: ${ }^{*} P<0.05$.

$\dagger$ For details of procedures and calculations, see pp. 212-214.

† Comparisons were performed using one-way ANOVA with differences between group means evaluated using the $t$ statistic. The appropriate standard error of difference values were, for 6 residual df, between amino acid tracer for calculations of whole-body amino acid flux 0.228 , proportional flux 0.01 and $k_{c} 0.013$. Differences between amino acid fluxes were significantly different $(P<0.05)$.

$\S$ Comparisons of leucine and phenylalanine kinetics for animals nos. 19 and 20 in Expts 1 and 2 were made using parallel curve analysis procedures (Ross, 1987). Values of $k_{c}$ were not different between experiments.

satisfy the requirements of milk protein synthesis and secretion, plus any alteration in gland constitutive protein mass and oxidative losses of AA associated with the turnover process. Of interest in the present study was the possible source of the immediate precursor for casein biosynthesis. Labelled casein was detected within 30-60 min from the start of the tracer infusions, in agreement with the observations of Wilde et al. (1989), suggesting that intermediate storage pools of newly synthesized casein are small. Under these circumstances a rapid rise in isotopic labelling of the casein might have been expected, especially with the frequent milking regime adopted. However, as in the pulse-chase studies with mammary gland explants of Wilde $e t$ al. (1989) and in the perfused goat mammary gland experiments of Roets et al. $(1979,1983)$, this did not occur, suggesting the presence of either intermediary intracellular sources with slower turnover rates, or of contributions from extracellular sources other than labelled free AA.

Of these latter sources, two are worthy of consideration. The vascular apolipoprotein 


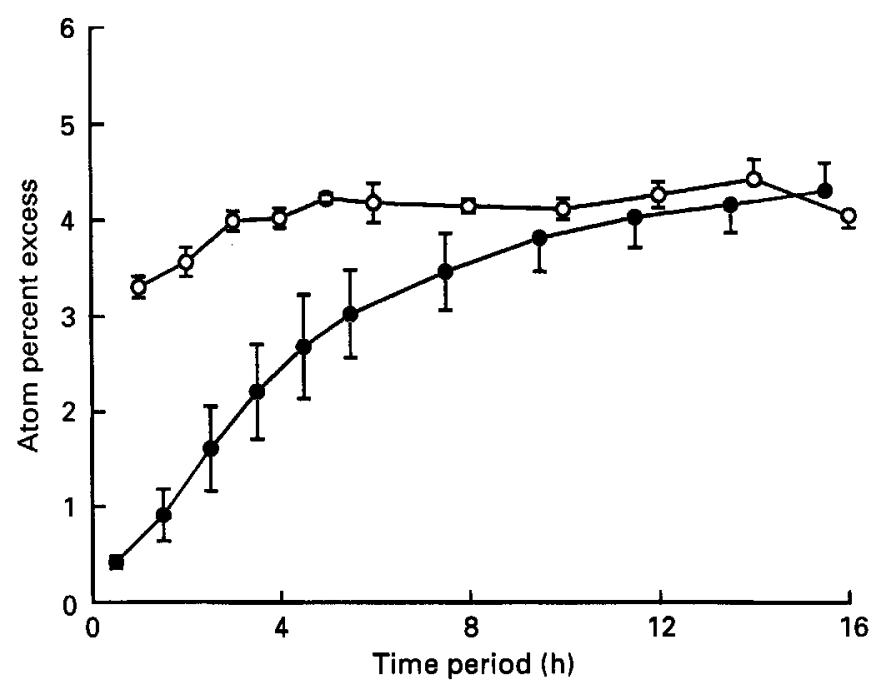

Fig. 2. Expt 2. Temporal changes in the isotopic enrichment of leucine in arterial blood (O) and in secreted milk casein (O) during a $16 \mathrm{~h}$ non-primed, continuous infusion of $\mathrm{L}-\left[1-{ }^{13} \mathrm{C}\right]$ leucine. Values are means with their standard errors for four goats. Values for milk casein have been plotted at the mid-point between milking times and blood values at the time that the samples were withdrawn.

pools have short half-lives (e.g. B-100, 1.7-2.8 h; Cryer et al. 1986) and this would increase their enrichment to an asymptote over the infusion period employed in the present experiments. The amounts of available protein from this source would appear limited, however, since in lactating goats of similar size and milk production the absolute rates of liver tissue protein synthesis were only 33-40 g/d (Champredon et al. 1990; Baracos et al. 1991), and only a small fraction of this (approximately 30\%) would be exported. Quantitatively this would seem insufficient to represent a major precursor of milk protein synthesis. Similarly, other known vascular pools of export proteins which would achieve a sufficiently substantial labelling within the experimental period are too small to provide major contributions.

The second possibility is that peptides arising from protein degradation within other tissues e.g. skeletal muscle, skin, and the gastrointestinal tract, may contribute. Backwell et al. (1994) have recently demonstrated that the mammary gland of goats can utilize peptide-bound AA for milk protein synthesis where labelled synthetic dipeptides are infused directly into the artery supplying the lactating gland. However, whether endogenous peptides are utilized remains to be proven. The present observations that the enrichment of casein-bound AA equalled or exceeded that of the blood free AA does not rule out such contributions for two reasons. First, jugular blood enrichments (used in Expt 1) are lower than arterial values and this would underestimate (by about $7 \%$ ) non-labelled peptide contributions. Additionally, since plasma free AA tend to have higher isotopic enrichments than the blood free AA measured in the present studies (Backwell et al. 1994), there could be scope for additional input of non-labelled peptide, if, as has been suggested by Heitmann \& Bergman (1980) and Hanigan et al. (1991), there is preferential tissue uptake of certain AA from the plasma. However, for extra-mammary gland peptides to contribute to the considerably enriched casein observed in both the present experiments would necessitate that the bulk of these peptides arise from rapidly turning over proteins. This could be consistent with contributions from the gastrointestinal tract, kidney and lung proteins, but for muscle and skin (major protein stores) to contribute, specific fractions would need to 
be involved, because the fractional synthesis rates of the total tissue proteins are lower than would be required to reconcile the isotope curves obtained in the current study (see Figs. 1 and 2).

A more likely explanation of the temporal enrichment patterns of the casein-bound AA involves the turnover of both casein and constitutive proteins in the mammary gland. During synthesis on membrane-bound polyribosomes nascent casein molecules undergo co-translational proteolytic cleavage to remove signal sequences, which comprise $7 \%$ of the molecule (Craig et al. 1979). These sequences are then probably degraded intracellularly, since they have not been detected in secreted milk (Baumrucker, 1985). In addition, pulsechase studies on mammary tissue explants from mid-pregnant rabbits (Razooki-Hasan $e t$ al. 1982) and late-lactating goats (Wilde et al. 1989), and in vivo estimates from the dairy goat (Oddy et al. 1988) indicate extensive intracellular degradation of newly synthesized and mature casein. However, Wilde et al. (1989) suggested that the susceptibility of casein to intracellular degradation is dependent upon the presence of an inhibitor of milk secretion found in the whey fraction of residual milk and under frequent milking such effect would be removed. Furthermore, the signal peptide would have the same enrichment as the rest of the casein molecule and would not therefore cause the slow rise to plateau observed.

A more favoured contributor to the observed casein kinetics would appear to be direct channelling of degradation products from mammary gland intracellular proteins into the immediate precursor pool for milk casein synthesis. This would require that at least some of the intracellular proteins have a high turnover rate. Indeed, Wilde et al. (1989) observed in pulse-chase studies on mammary explants that the specific radioactivity of proline increased to a peak followed by a period of stable isotopic incorporation which the authors suggested indicated continued synthesis of casein from a residual pool of highly labelled precursor(s). In addition, rapid fractional synthetic rates have already been reported for mammary tissue proteins $(40-130 \% / d$; Champredon et al. 1990; Baracos et al. 1991), and under first-order conditions for protein breakdown and inconsequential change in mammary gland tissue protein pool size, then recycled labelled AA will return into the intracellular AA pool. In the present study the $k_{c}$ values for the rise of casein-bound AA enrichment indicated a half-life of between 1.5-5.0 h, which should also be that of the precursor pool proteins. Although these are lower than the values of $13-41 \mathrm{~h}$ which can be derived from the data of Champredon et al. (1990) and Baracos et al. (1991) for mixed mammary gland proteins in lactating goats, some individual labile proteins could have much faster turnover rates.

One of the main objectives of the present study was to examine whether stage of lactation altered the transfer kinetics of blood free AA into milk protein. Perhaps the two most important findings to arise from these preliminary studies were first that although during the transition from post-peak to late lactation the contribution of milk protein output to whole-body flux declined from 0.30 to $0 \cdot 19$, the non-milk protein flux remained relatively constant. This substantiates the lack of change in fractional synthesis rates of a variety of tissues observed in dry and non-lactating goats by Baracos et al. (1991). The second finding was that within the mammary gland itself there seemed to be little alteration in the relative contributions of the different substrates to the immediate precursor pool for milk casein biosynthesis as indicated by the parallel curve analyses on the $k_{c}$ values for the casein enrichment curves of animals nos. 19 and 20 in Expts 1 and 2. These observations, if substantiated by further experimentation, would allow a degree of simplification when it comes to modelling the dynamics of milk protein output in animals at different stages of lactation. 
The work reported here formed part of a collaborative project funded by a consortium of the Ministry of Agriculture Fisheries and Food, BP Nutrition (UK) Ltd., the Milk Marketing Board of England and Wales and the Agricultural and Food Research Council.

\section{REFERENCES}

Agricultural and Food Research Council (1984). Report of the Protein Group of the Agricultural Research Council Working Party on the Nutrient Requirements of Ruminants. Supplementary Report to Chapter 4 $(A R C, 1980)$. Farnham: Commonwealth Agricultural Bureaux.

Agricultural and Food Research Council (1992). AFRC Technical Committee on Responses to Nutrients. Report no. 9. Nutrition Abstracts and Reviews, Series B: Livestock and Feeding 62, 803-817.

Backwell, F. R. C., Bequette, B. J., Wilson, D., Calder, A. G., Wray-Cahen, D., Metcalf, J. A., MacRae, J. C., Beever, D. E. \& Lobley, G. E. (1994). The utilization of dipeptides by the caprine mammary gland for milk protein synthesis. American Journal of Physiology (In the Press).

Baracos, V. E., Brun-Bellut, J. \& Marie, M. (1991). Tissue protein synthesis in lactating and dry goats. British Journal of Nutrition 66, 451-465.

Baumrucker, C. R. (1985). Amino acid transport systems in bovine mammary tissue. Journal of Dairy Science $\mathbf{6 8}$, 2436-2451.

Calder, A. G. \& Smith, A. (1988). Stable isotope ratio analysis of leucine and ketoisocaproic acid in blood plasma by gas chromatography/mass spectrometry. Use of tertiary butyldimethylsilyl derivatives. Rapid Communications in Mass Spectrometry 2, 14-16.

Champredon, C., Debras, E., Mirand, P. P. \& Arnal, M. (1990). Methionine flux and tissue protein synthesis in lactating and dry goats. Journal of Nutrition 120, 1006-1015.

Craig, R. K., Perera, P. A. J., Mellor, A. \& Smith, A. E. (1979). Initiation and processing in vivo of the primary translation products of guinea-pig caseins. Biochemical Journal 184, 261-267.

Cryer, D. R., Matsushima, T., Marsh, J. B., Yudkoff, M., Coates, P. M. \& Cortner, J. A. (1986). Direct measurement of apolipoprotein $\mathbf{B}$ synthesis in human very low density lipoprotein using stable isotopes and mass spectrometry. Journal of Lipid Research 27, 508-516.

Eggum, B. O. (1968). Aminosyrekoncentration og proteinkvalitet (Amino acid concentrations and protein quality) Kobenhavn: Stougaards Forlag.

Hanigan, M. D., Calvert, C. C., DePeters, E. J., Reis, B. L. \& Baldwin, R. L. (1991) Whole blood and plasma amino acid uptakes by lactating bovine mammary glands. Journal of Dairy Science 74, 2484-2490.

Heitmann, R. N. \& Bergman, E. N. (1980). Transport of amino acids in whole blood and plasma of sheep. American Journal of Physiology 239, E242-E247.

McKenzie, H. A. (1971). Whole casein: isolation, properties and zone electrophoresis. In Milk Proteins, Chemistry and Molecular Biology, pp. 87-116 [H. A. McKenzie, editor]. New York and London: Academic Press.

MacRae, J. C., Buttery, P. J. \& Beever, D. E. (1988). Nutrient interactions in the dairy cow. In Nutrition and Lactation in the Dairy Cow, pp. 55-75 [P. C. Garnsworthy, editor]. London: Butterworths.

Oddy, V. H., Lindsay, D. B. \& Fleet, I. R. (1988). Protein synthesis and degradation in the mammary gland of lactating goats. Journal of Dairy Research 55, 143-154.

Razooki-Hasan, H., White, D. A. \& Mayer, R. J. (1982). Extensive degradation of newly synthesised casein in mammary explants in organ culture. Biochemical Journal 202, 133-138.

Roets, E., Massart-Leën, A-M., Peeters, G. \& Verbeke, R. (1983). Metabolism of leucine by the isolated perfused goat udder. Journal of Dairy Research 50, 413424.

Roets, E., Massart-Leën, A-M., Verbeke, R. \& Peeters, G. (1979). Metabolism of $\left[\right.$ U- ${ }^{14}$ C; $\left.2,3-{ }^{3} \mathrm{H}\right]-\mathrm{L}-\mathrm{valine}$ by the isolated perfused goat udder. Journal of Dairy Research 46, 47-57.

Ross, G. J. S. (1987). MLP, Maximum Likelihood Program. Version 3.08. Oxford: Numerical Algorithms Group.

Wilde, C. J., Addey, C. V. P. \& Knight, C. H. (1989). Regulation of intracellular casein degradation by secreted milk proteins, Biochimica et Biophysica Acta 992, 315-319. 